http://dx.doi.org/10.18778/1509-877X.2018.02.01

\title{
OPODATKOWANIE NIEODPŁATNEGO NABYCIA WŁASNOŚCI RZECZY I PRAW MAJĄTKOWYCH W PRAWIE PODATKOWYM POLSKI I LITWY WYBRANE PROBLEMY
}

\begin{abstract}
Streszczenie. Z przedstawionych porównań wynika ewidentnie, że obowiązujący w Republice Litewskiej podatek od spadków jest podatkiem prostym, nieskomplikowanym zarówno pod względem prawnym, jak i finansowym. Tym samym nie wywołuje on poważniejszych problemów praktycznych ani w jego płaceniu, ani w wymiarze. Jego obliczenie i wymiar są przyjazne dla podatników. Na szczególną uwagę zasługują takie rozwiązania, jak obniżenie podstawy opodatkowania o 30\%, brak odliczania długów i ciężarów oraz skomplikowanej procedury ich ustalania, respektowanie zasady unikania podwójnego opodatkowania czy brak instytucji ponownego powstania obowiązku podatkowego.

Tego nie można powiedzieć o obowiązującym w Polsce podatku od spadków i darowizn. Jedyne, co można powiedzieć na korzyść rozwiązań obowiązujących w Polsce, to to, że zakres przedmiotowy tego podatku jest szerszy, co prowadzi do niemożliwości poddania wielu przedmiotów nabycia wyższym podatkiem dochodowym od osób fizycznych.

Autor chce tym tekstem rozpocząć cykl publikacji przybliżających polskim podatnikom, organom podatkowym, a także ustawodawcy rozwiązania prawne obowiązujące w zakresie opodatkowania nieodpłatnego nabycia własności rzeczy i praw majątkowych w innych wybranych krajach europejskich. Polska ustawa o podatku od spadków i darowizn jest niezwykle skomplikowana, generująca spory podatkowe, niesprzyjająca nawiązywaniu poprawnych relacji między podatnikami a organami podatkowymi i, niewątpliwie, także rodząca konflikty rodzinne.
\end{abstract}

Słowa kluczowe: spadek, darowizna, zapis windykacyjny, zapis zwykły, dalszy zapis, podmiot, przedmiot opodatkowania, podstawa opodatkowania, ulgi i zwolnienia, podatek od spadku obowiązujący w Republice Litewskiej, ustawa o podatku od spadków i darowizn

* Sędzia Naczelnego Sądu Administracyjnego, e-mail: babiarzstefan@gmail.com 
1. WPROWADZENIE

Celem niniejszego artykułu jest analiza językowa, systemowa i porównawcza tekstów wybranych ustaw podatkowych litewskich i polskich w zakresie opodatkowania nieodpłatnego nabycia własności rzeczy i praw majątkowych. Analiza obejmie podmiot, przedmiot opodatkowania, moment powstania obowiązku podatkowego i stawkę podatku oraz zwolnienia i ulgi podatkowe, a także naliczenie podatku i jego zapłatę oraz inne wybrane zagadnienia.

W przedstawionej analizie autor chce zwrócić uwagę na to, czy przyjęte rozwiązania są podobne i w jakim stopniu, czy są oraz dlaczego korzystne dla podatników, a także czy są to rozwiązania proste i zrozumiałe, niewywołujące kontrowersji. Przedmiotem porównania będą objęte następujące akty prawne:

\section{Polski}

- Konstytucja Rzeczypospolitej Polskiej z dnia 2 kwietnia 1997 r. ${ }^{1}$ (dalej: Konstytucja RP),

- Ustawa z dnia 28 lipca 1983 r. o podatku od spadków i darowizn² (dalej: u.p.s.d.),

- Rozporządzenie Ministra finansów z dnia 20 lipca 2015 r. w sprawie wzoru zgłoszenia o nabyciu własności rzeczy lub praw majątkowych ${ }^{3}$ (dalej: rozporządzenie w sprawie wzoru zgłoszenia),

- Ustawa z dnia 26 lipca 1991 r. o podatku dochodowym od osób fizycznych $^{4}$ (dalej: u.p.d.o.f.),

- Ustawa z dnia 29 sierpnia 1997 r. - Ordynacja podatkowa ${ }^{5}$ (dalej: o.p.);

Litwy

- Konstytucja Republiki Litewskiej z dnia 6 listopada 1996 r. ${ }^{6}$ (dalej: Konstytucja RL),

1 Dz.U. z 1997 r., Nr 78, poz. 483 ze zm.

2 Dz.U. z 2018 r., poz. 644.

3 Dz.U. z 2015 r., poz. 2060.

${ }^{4}$ Dz.U. z 2018 r., poz. 200 ze zm.

5 Dz.U. z 2018 r., poz. 800 ze zm.

${ }^{6}$ Rejestr Aktów Prawnych, kod identyfikacyjny 0921010KONSRG922324. 
- Ustawa Republiki Litewskiej z dnia 10 grudnia 2002 r. o podatku od spadków ${ }^{7}$ - wersja skonsolidowana (dalej: ustawa Republiki Litewskiej o podatku od spadków),

- nieobowiązująca (uchylona 10 grudnia 2002 r. ustawą nr IX-1239 od dnia 1 stycznia 2003 r.) - Ustawa Republiki Litewskiej z dnia 13 czerwca 1995 r., Nr I-935 o podatku od spadków i darowizn ${ }^{8}$ (dalej: nieobowiązująca ustawa Republiki Litewskiej o podatku od spadków i darowizn),

- Rozporządzenie Rządu Republiki Litewskiej z dnia 13 stycznia 2003 r. Nr 24 dotyczące zasad obliczania podstawy opodatkowania spad$\mathrm{ku}^{9}$ (dalej: rozporządzenie wykonawcze RL do ustawy o podatku od spadków),

- Ustawa Republiki Litewskiej z dnia 2 lipca 2002 r. Nr IX-1007 o podatku dochodowym od osób fizycznych ${ }^{10}$ - tekst skonsolidowany,

- Ustawa Republiki Litewskiej z dnia 13 kwietnia 2004 r. o ordynacji podatkowej ${ }^{11}$ (dalej: Ordynacja podatkowa RL),

- Rozporządzenie Rządu Republiki Litewskiej z dnia 29 stycznia 2003 r. $\mathrm{Nr} 133$ w sprawie zatwierdzania zasad ustalania w niektórych przypadkach ceny mienia nabywanego przez osoby fizyczne nieprowadzące działalności na własny rachunek (dalej: rozporządzenie wykonawcze do ustawy Republiki Litewskiej o podatku dochodowym od osób fizycznych).

Zasadne jest pytanie o to, dlaczego należy porównywać powyższe elementy konstrukcji podatku. Przede wszystkim dlatego, że elementy te w istocie powinny występować w każdym podatku unormowanym w danej ustawie podatkowej ${ }^{12}$. Trzeba wszakże brać pod uwagę także to, że pojęcia: „elementy konstrukcji podatku”13 czy „elementy podatku”14 albo „techniczne elementy podatku” ${ }^{15}$, czy w końcu „elementy techniki podatkowej”16

7 Žin. 2002, Nr 123 - 5531.

8 Žin. 2002, Nr 123 - 5531.

9 Žin. 2004, Nr 109 - 4082.

10 Rejestr Aktów Prawnych, kod identyfikacyjny 1041010ISTAOIX-2112.

11 Žin. 2004, Nr 63 - 2243 ze zm.

12 A. Kostecki, Elementy konstrukcji podatku, [w:] System instytucji prawno-finansowych PRL, t. 3: Instytucje budżetowe, cz. 2: Dochody i wydatki budżetu, red. M. Weralski, Ossolineum, Wrocław 1985, s. 152-153.

13 K. Ostrowski, Prawo finansowe. Zarys ogólny, Warszawa 1970, s. 144.

${ }^{14}$ N. Gajl, Finanse i prawo finansowe, Warszawa 1980, s. 204.

15 H. Reniger, Prawo finansowe, red. L. Kurowski, Warszawa 1955, s. 311.

16 Z. Fedorowicz, Finanse w gospodarce socjalistycznej, Warszawa 1966, s. 396. 
nie są używane jednoznacznie. Spory na ten temat istnieją też na Litwie ${ }^{17}$. Należy jednak przyjąć termin „elementy konstrukcji podatku” jako najbardziej odpowiadający istocie omawianego zagadnienia prawnoporównawczego i nawiązujący do treści aktów normatywnych materialnego prawa podatkowego. Trzeba też zwrócić uwagę na to, że trzy podstawowe elementy konstrukcji podatku, czyli podatnik, przedmiot i podstawa opodatkowania, występują w hipotezie normy prawnopodatkowej, a pozostałe elementy, takie jak: stawka podatkowa, termin i sposób zapłaty podatku, składają się na treść dyspozycji normy prawa podatkowego ${ }^{18}$. Zwolnienia i ulgi podatkowe mieszczą się, w zależności od tego, czego dotyczą, albo w hipotezie, albo w dyspozycji normy prawa podatkowego. W polskiej literaturze prawa podatkowego używa się określenia „ulga podatkowa” w znaczeniu „mechanizm zmniejszający wysokość podatku, który łączy się z podmiotem lub przedmiotem opodatkowania"19. Mechanizm ten polega na:

a) zmniejszeniu podstawy opodatkowania;

b) obniżeniu stawek podatkowych;

c) bezpośrednim obniżeniu kwoty podatku.

Zwolnienia podatkowe $z$ kolei oznaczają ograniczenie podmiotowego lub przedmiotowego zakresu podatku ${ }^{20}$, przy czym mogą też występować zwolnienia o charakterze mieszanym: podmiotowo-przedmiotowym. Różnica między ulgami a zwolnieniami podatkowymi w polskim piśmiennictwie podatkowym polega na tym, że ulgi mają charakter ilościowy, a zwolnienie oznacza wyłączenie określonej kategorii podmiotów lub przedmiotów spod opodatkowania. Ulgi w istocie rzeczy zmniejszają tylko rozmiary opodatkowania w tym podatku. Nie chodzi tu o rezygnację z opodatkowania, jak w przypadku zwolnienia. Łączy je zaś jedno: że są to niesamoistne elementy konstrukcji podatku. Z kolei w piśmiennictwie z zakresu prawa podatkowego oraz w uregulowaniach zawartych w ustawie o ordynacji podatkowej Republiki Litewskiej w art. 2 ust. 8 postanawia się, że „ulga podatkowa to określone w ustawie podatkowej wobec podatników lub ich grupy wyjątkowe warunki opodatkowania, które są bardziej korzystne w porównaniu ze zwykłymi warunkami”. Zgodnie z art. 4 ust. 1 tej ustawy ulgi podatkowe należy wiązać nie tylko z podatkami, ale też z zapła-

17 A. Medelienĕ, B. Sudavičius, Mokesčius teisě, Vilnius 2011, s. 78 i n.; System finansów publicznych Polski i Litwy, red. S. Presnarowicz, B. Sudavičius, Białystok 2017, s. 144.

18 A. Kostecki, Elementy..., s. 192.

19 W. Nykiel, Ulgi i zwolnienia w konstrukcji prawnej podatku, Warszawa 2002, s. 23.

20 Ibidem, s. 85. 
tą kar i odsetek za zwłokę oraz zawarciem umowy kredytu podatkowego ${ }^{21}$. W litewskiej literaturze prawniczej rozróżnia się rozmaite formy ulg podatkowych, tj.: zwolnienie od podatku (stosowanie wyjątków podatkowych), obniżenie podstawy opodatkowania, zmniejszenie kwoty podatku (stosowanie ulg podatkowych $)^{22}$. Natomiast zwolnienie od podatku to sytuacja, w której podmiot lub przedmiot opodatkowania, spełniający kryteria przewidziane $\mathrm{w}$ ustawie, jest zwolniony od zapłaty określonego podatku (lub jego części) albo jest wyłączony z kręgu podmiotów lub przedmiotów opodatkowania, co jest wyjątkiem od opodatkowania, mimo że w świetle ustawy pozostaje podatnikiem podatku (przedmiotem opodatkowania). Oznacza to w konsekwencji, że podobnie jak w Polsce, zwolnienie podatkowe nie wyłącza z zakresu podmiotowego danego podatku. Uniemożliwia to więc równocześnie poddanie tego podatnika, czy też przedmiotu opodatkowania, innemu podatkowi. Do tego prowadzi wyłączenie od opodatkowania. Można zatem powiedzieć, że z historycznego punktu widzenia nie ma zasadniczych różnic między zwolnieniem podatkowym w Polsce i na Litwie. Różnice występują natomiast w zakresie rozumienia i przyjętych rozwiązań w odniesieniu do ulg podatkowych. Rozwiązanie litewskie jest niewątpliwie szersze, tym samym stwarza możliwości bardziej elastycznego reagowania na sytuacje poszczególnych podatników.

Biorąc pod uwagę powyższe, uznałem za konieczne dla uzyskania jasnego efektu porównawczego oparcie rozważań prawnoporównawczych na powyższej polskiej konstrukcji elementów konstrukcyjnych podatku i rozumienia pojęć: ulga oraz zwolnienie podatkowe.

Natomiast przedmiotem badań prawnoporównawczych, o które tu chodzi, nie może być stosunek prawnopodatkowy i jego elementy, albowiem ze względu na rozumienie tego pojęcia zakres rozważań prawnoporównawczych byłby zbyt wąski. Można byłoby wówczas objąć rozważaniami tylko zagadnienia związane $\mathrm{z}$ możliwym stosunkiem podatkowym (podmiot, przedmiot, podstawa opodatkowania) oraz formalnym stosunkiem podatkowym (składanie zeznań i deklaracji podatkowych, prowadzenie ksiąg podatkowych oraz udzielanie informacji organom podatkowym) ${ }^{23}$. Zagadnienia te nie byłyby jednak reprezentatywne dla poczynienia badań prawnoporównawczych.

21 System finansów publicznych..., s. 149.

22 A. Medelienĕ, B. Sudavičius, Mokesčius teisě, s. 97.

23 A. Nita, Stosunek prawnopodatkowy, Kraków 1999, s. 30-33. 


\section{Konstytucja Rzeczypospolitej Polskiej i Konstytucja Republiki Litewskiej a podatki}

Zarówno polski podatek od spadków i darowizn (art. 4 ust. 1 pkt 1 lit. g Ustawy z dnia 13 listopada 2003 r. o dochodach jednostek samorządu terytorialnego ${ }^{24}$ ), jak i litewski podatek od spadków jest dochodem jednostki samorządu terytorialnego ${ }^{25}$. Z tego też powodu wydaje się celowe pominięcie rozważań nad uprawnieniem jednostek samorządu terytorialnego w zakresie władztwa podatkowego w odniesieniu do wybranych elementów.

Zgodnie z art. 67 pkt 15 Konstytucji RL „Sejm ustanawia podatki państwowe i inne obowiązkowe opłaty”. Natomiast stosownie do art. 121 ust. 2 Konstytucji RL „Rady samorządowe mają prawo nakładać, w trybie przewidzianym przez ustawę, podatki lokalne, a także w ramach swego budżetu mogą obniżać przewidziane opłaty i podatki”. Konstytucja RP w art. 168 postanawia, że ,jednostki samorządu terytorialnego mają prawo ustalania wysokości podatków i opłat lokalnych w zakresie określonym w ustawie”. Unormowania zawarte $\mathrm{w}$ tym zakresie w obu ustawach zasadniczych są $\mathrm{w}$ istocie zbieżne, $\mathrm{z}$ tym że uregulowanie zawarte $\mathrm{w}$ Konstytucji RL wprost stanowi, iż prawo nakładania podatków mają tylko rady samorządowe, ale już nie inne organy samorządu. Wydawałoby się, że rady samorządowe RL mają prawo nakładania, więc nie ustalania podatków. Jednakże przy interpretacji tego przepisu należy uwzględnić treść art. 127 ust. 3 Konstytucji RL. Można zasadnie sądzić, że jest to rozwiązanie podobne do polskiego. Wskazuje się w art. 121 ust. 2 aktu litewskiego, że prawo do nakładania podatków i opłat oraz tryb ich nakładania przez rady samorządowe muszą być przewidziane przez ustawę. To oznacza, że nie jest dopuszczalne określenie tego uprawnienia i trybu w aktach niższego rzędu. Wydaje się, że jest to uprawnienie szersze niż zawarte w art. 168 Konstytucji RP, które wskazuje na prawo jednostek samorządu terytorialnego (organów stanowiących tych jednostek) ustalania wysokości podatków i opłat lokalnych w zakresie określonym w ustawie. Oznacza to, że organy stanowiące jednostek samorządu terytorialnego w istocie rzeczy nie mogą w Rzeczypospolitej Polskiej ustanawiać nowych podatków i opłat lokalnych, ale mogą decydować o wysokości obciążeń podatkowych w granicach wskazanych w ustawie ${ }^{26}$.

${ }^{24}$ Dz.U. z 2017 r., poz. 1453 ze zm.

25 Artykuł 10 ustawy Republiki Litewskiej o podatku od spadków.

${ }^{26}$ J. Zawora, Samodzielność finansowa gmin w świetle uwarunkowań prawnych i samorządowych wydatków inwestycyjnych, „Finanse Komunalne” 2014, nr 10, s. 22-33. 
Wydaje się też jednak, że pogląd powyższy jest postawiony zbyt wąsko, a mianowicie, jeżeli zwrócić uwagę na treść art. 15 ust. 1, art. 17 ust. 1 i ust. 1a oraz art. 17a ust. 1 Ustawy z dnia 12 stycznia 1991 r. o podatkach i opłatach lokalnych ${ }^{27}$ (dalej: u.p.o.l.), to w istocie rzeczy opłatę targową, opłatę miejscową czy uzdrowiskową albo opłatę reklamową ustanawia się w powyższej ustawie (art. 1 pkt 4-5b u.p.o.l.), ale wprowadzić je na terenie gminy może tylko rada gminy, która także może ustanawiać stawki opłat, oczywiście niższe niż określone jako maksymalne w tej ustawie.

Co ważne, zbliżone uprawnienie znajduje się w art. 121 Konstytucji RL, z którego to przepisu wynika kompetencja rad samorządowych do obniżenia przewidzianych opłat, przy czym kryterium są tutaj „ramy budżetu”. Można tu postawić tezę, że rozwiązanie to jest porównywalne z rozwiązaniami polskimi, aczkolwiek art. 7 ust. 3, art. 12 ust. 4, art. 19 ust. 3 u.p.o.l., art. 7 ust. 3 Ustawy z dnia 30 października 2002 r. o podatku leśnym ${ }^{28}$ czy art. 13e Ustawy z dnia 15 listopada 1984 r. o podatku rolnym ${ }^{29}$, dające radom gmin prawo do wprowadzenia innych zwolnień przedmiotowych, wprost nie mówią o konieczności uwzględnienia „ram budżetu”. Powyższe jest oczywiste, bo rada gminy, uchwalając budżet, musi liczyć się z obowiązkiem zaspokojenia zbiorowych potrzeb wspólnoty ${ }^{30}$.

Omawiając ramy konstytucyjne ustanowienia podatków i opłat, nie można nie wspomnieć o art. 127 ust. 3 Konstytucji RL, stosownie do którego „Podatki i inne wpływy do budżetów oraz opłaty wyrównawcze określają ustawy Republiki Litewskiej”. W przepisie tym używa się określenia „budżetów", co oznacza, że chodzi w nim nie tylko o podatki zasilające budżet państwa, ale i budżety samorządowe Republiki Litewskiej.

Przepis ten wprawdzie napisany jest dość ogólnie, jednak uznaje się, że „określenie istotnych elementów konstrukcyjnych podatku w ustawie podatkowej dotyczącej poszczególnych podatków jest przesłanką konieczną do tego, by konkretna osoba była nie tylko zobowiązana do zapłaty konkretnego podatku, ale też by mogła należycie wykonać ten obowiązek"31. Niewątpliwie jest tak, albowiem określenie „podatki [...] określają ustawy

27 Dz.U. z 2017 r., poz. 1785 ze zm.

28 Dz.U. z 2017 r., poz. 1821.

29 Dz.U. z 2017 r., poz. 1892.

30 Artykuł 7 ust. 1 pkt 1-20 Ustawy z dnia 8 marca 1990 r. o samorządzie gmin (Dz.U. z 2018 r., poz. 994 ze zm.).

31 A. Medelienĕ, B. Sudavičius, Mokesčius teisě, s. 78; System finansów publicznych..., S. 144. 
Republiki Litewskiej" można i należy rozumieć szeroko, tzn. jako nie tylko wprowadzające dany rodzaj podatku czy opłat, ale i ich istotnych elementów konstrukcyjnych. Przepis ten należy utożsamiać z art. 217 Konstytucji RP, stosownie do którego „Nakładanie podatków, innych danin publicznych, określenie podmiotów opodatkowania i stawek podatkowych, a także zasad przyznawania ulg i umorzeń oraz kategorii podmiotów zwolnionych od podatków następuje w drodze ustawy".

3. ZAKRES PODMIOTOWO-PRZEDMIOTOWY USTAW O PODATKU OD SPADKóW W POLSCE I NA LiTWIE

Charakterystyczne jest to, że określenie ogólne podatnika znajduje się zarówno w litewskiej, jak i polskiej Ordynacji podatkowej. Zgodnie z art. 1 ust. 15 Ordynacji podatkowej RL „Podatnik to osoba, wobec której w ustawie podatkowej przewidziano obowiązek zapłaty podatku”. Natomiast zgodnie z art. 7 ust. 1 i 2 o.p. „Podatnikiem jest osoba fizyczna, osoba prawna lub jednostka organizacyjna niemająca osobowości prawnej podlegająca na mocy ustaw podatkowych obowiązkowi podatkowemu”, a „Ustawy podatkowe mogą ustanawiać podatnikami inne podmioty niż wymienione $\mathrm{w} \$ 1$ ”. Porównując te regulacje, nie wydaje się, by istniały między nimi jakieś istotne różnice, gdyż podleganie obowiązkowi podatkowemu w istocie sprowadza się (zob. ust. 4 o.p.) do obowiązku zapłaty podatku, a ten tak czy inaczej zawsze regulują ustawy podatkowe (przepisy materialnoprawne). Pojęcie „osoba” odnosi się do osoby fizycznej, osoby prawnej czy jednostki organizacyjnej niemającej osobowości prawnej.

Od razu trzeba zwrócić uwagę, że ustawa o podatku od spadków obowiązująca w Republice Litewskiej obejmuje tylko opodatkowanie „spadków mieszkańców (obywateli) zarówno stałych, jak i tymczasowych" (art. 1 w zw. z art. 2 pkt 1 ustawy Republiki Litewskiej o podatku od spadków). Oznacza to, że zakres przedmiotowy opodatkowania podatkiem od spadków i darowizn w Polsce jest szerszy, gdyż obejmuje także inne tytuły nabycia własności rzeczy lub praw majątkowych, takie jak nabycie ich tytułem:

a) dziedziczenia, zapisu zwykłego, dalszego zapisu, zapisu windykacyjnego i polecenia testamentowego;

b) darowizny i polecenia darczyńcy;

c) zasiedzenia;

d) nieodpłatnego zniesienia współwłasności; 
e) zachowku, jeżeli uprawniony nie uzyskał go w postaci uczynionej przez spadkodawcę darowizny lub w drodze dziedziczenia albo w postaci zapisu;

f) nieodpłatnej renty, użytkowania oraz służebności.

Podatkowi od spadków i darowizn w Polsce podlega również nabycie praw do wkładu oszczędnościowego na podstawie dyspozycji wkładem na wypadek śmierci (nie wchodzi do spadku po osobie zmarłej w określonej ściśle kwocie) oraz nabycie jednostek uczestnictwa na podstawie dyspozycji uczestnika funduszu inwestycyjnego otwartego albo specjalistycznego funduszu inwestycyjnego otwartego na wypadek śmierci (także nie wchodzi do spadku po osobie zmarłej w określonej ściśle wysokości). Ten przedmiot opodatkowania podatkiem od spadków wprost nie jest wymieniony w ustawie o podatku od spadku obowiązującej w Republice Litewskiej.

Okoliczność, że ustawa o podatku od spadków obowiązująca na Litwie nie obejmuje swym zakresem przedmiotowym tych tytułów nabycia, które obejmuje polska ustawa o podatku od spadków i darowizn, nie oznacza, że nabycie tytułem darowizny na Litwie nie podlega opodatkowaniu. Zgodnie bowiem z Ustawą Republiki Litewskiej z dnia 2 lipca 2002 r. o podatku dochodowym od osób fizycznych darowizny otrzymane w trybie tego aktu na podstawie umowy darowizny i sponsoringu są zwolnione od podatku dochodowego. Zwolniony jest też od tego podatku dochód otrzymany w spadku, który jest przedmiotem podatku zgodnie z przepisami prawa regulującymi na Litwie podatek od spadków, a także dochód otrzymany w drodze darowizny od małżonka, dzieci (dzieci adoptowanych), rodziców (rodziców zastępczych), braci, sióstr, wnuków i dziadków, jak również kwota (wartość dochodu otrzymanego od innych osób fizycznych w drodze darowizny, nieprzekraczająca 2500 euro (art. 17 ust. 1 pkt 25 i 26 ustawy o podatku dochodowym od osób fizycznych Republiki Litewskiej). Oznaczałoby to, że darowizny od innych osób i w kwocie wyższej podlegają podatkowi dochodowemu. Potwierdza to treść art. 17 ust. 2 tej ustawy, z którego wynika, że dochód uzyskany w drodze darowizny od innych osób niż małżonek, dzieci (dzieci adoptowane), rodzice (rodzice zastępczy), bracia, siostry, wnuki i dziadkowie nie jest zwolniony od podatku, jeżeli osoba fizyczna uzyskała odpowiedni dochód od osób fizycznych, których stałe miejsce zamieszkania znajduje się za granicą.

Należy jednak zwrócić uwagę na to, że obowiązująca poprzednio, do dnia 1 stycznia 2003 r. ustawa Republiki Litewskiej z dnia 13 czerwca 1995 r. 
Nr I-935 o podatku od spadków i darowizn opodatkowywała tym podatkiem również nabycie nieruchomości i rzeczy ruchomych (w tym akcje, obligacje, weksle i inne papiery wartościowe) w drodze darowizny. Poddanie nabycia w drodze darowizny opodatkowaniu podatkiem dochodowym od osób fizycznych, a nie podatkiem od spadków jest niewątpliwie niekorzystne dla podatników tego podatku, gdyż zasadnicza stawka podatku dochodowego (art. 6 ustawy) wynosi 15\%, natomiast stawka podatku od spadków, nawet maksymalna, wynosi $10 \%$ podstawy opodatkowania. Rozwiązanie to przypomina polski art. 2 ust. 1 pkt 3 u.p.d.o.f., zgodnie z którym przepisów ustawy o podatku dochodowym od osób fizycznych nie stosuje się do przychodów podlegających przepisom o podatku od spadków i darowizn. Oznacza to, że zarówno na Litwie, jak i w Polsce ustawa o podatku od spadków (w Polsce ustawa o podatku od spadków i darowizn) to przepisy lex specialis w stosunku do ustaw o podatku dochodowym od osób fizycznych.

\section{Podmiot PODATKu OD SPADKu (PODATNIK)}

Stosownie do postanowień art. 3 ustawy Republiki Litewskiej o podatku od spadku podatnikiem tego podatku są mieszkańcy (obywatele), a określenie „mieszkaniec” oznacza mieszkańca stałego i tymczasowego. Określenie to nie zostało bliżej zdefiniowane w tej ustawie i w związku z tym w art. 2 ust. 2 i 3 ustawy odsyła się do bliższego rozumienia tego pojęcia zawartego w ustawie o podatku dochodowym od osób fizycznych. Ta ustawa wyraźnie rozróżnia dwie grupy podatników, tj. rezydentów (osoby fizyczne na stałe zamieszkujące na terenie Republiki Litewskiej) oraz nierezydentów (osoby fizyczne niebędące rezydentami), które uzyskały przychody na terenie Litwy ${ }^{32}$. To rozwiązanie oznaczałoby, że nabycie przez rezydenta Litwy majątku położonego za granicą podlegałoby podatkowi dochodowemu od osób fizycznych, a nie podatkowi od spadku. Zgodnie zaś z art. 1 ust. 1 i art. 2 u.p.s.d. polskiemu podatkowi od spadku i darowizn podlega nabycie własności rzeczy i praw majątkowych przez osobę będącą obywatelem polskim lub mającą miejsce stałego pobytu na terytorium Rzeczypospolitej Polskiej. W Polsce zatem kryterium tym jest obywatelstwo i miejsce stałego pobytu, a nie tylko miejsce stałego czy tymczasowego zamieszkiwania,

${ }^{32}$ L. Etel, Opodatkowanie dochodu w wybranych krajach Europy Środkowej $i$ Wschodniej, Białystok 2006, s. 148-151; A. Mikielewicz, Warunki życia i pracy w krajach Europejskiego Obszaru Gospodarczego, Białystok 2012, s. 11-12. 
jak w Republice Litewskiej ${ }^{33}$. Rozwiązania obowiązujące na gruncie obu porównywanych ustaw prowadzą też do jednolitego wniosku, że podatnikami tych podatków są tylko osoby fizyczne (art. 2 ust. 2 i 3 ustawy Republiki Litewskiej o podatku od spadku oraz art. 1 ust. 1 i art. 2 u.p.s.d.). W konsekwencji nabycie własności rzeczy i praw majątkowych przez osoby prawne czy jednostki organizacyjne niemające osobowości prawnej podlegać będzie podatkowi dochodowemu od osób prawnych. Przepisy prawa podatkowego litewskiego nie używają określenia ,jednostka organizacyjna niemająca osobowości prawnej”, lecz czynią podatnikiem „organizacje i dowolny zorganizowany w inny sposób podmiot prawny, niezależnie od łączących go z państwem litewskim, które ustanowiło podatek, stosunków prawnych (tj. niezależnie od tego, czy należy do jego jurysdykcji, czy nie)"34.

\section{Przedmiot opodatkowania}

W tym elemencie konstrukcyjnym podatku różnice między uregulowaniami litewskimi i polskimi są największe. Trudno ustalić, jakie są tego przyczyny, można przypuszczać, że doświadczenia historyczne obu państw. W Polsce bowiem nieodpłatne nabycie własności rzeczy i praw majątkowych podlegało odrębnemu opodatkowaniu już w okresie międzywojennym $^{35}$ oraz powojennym ${ }^{36}$. W związku z tym należy zauważyć, że opodatkowaniem podatkiem od spadku na Litwie, w przypadku gdy podatnikiem jest stały mieszkaniec Litwy, podlega jako przedmiot spadek (art. 4 ust. 1 ustawy), przy czym ustawa w art. 2 ust. 4 definiuje pojęcie „mienie”. Jest nim „nieruchomość, rzeczy ruchome, papiery wartościowe i pieniądze”. Nie jest jasne, czy określenie „mienie” ma wpływ na ograniczenie zakresu rozumienia pojęcia „spadek”, ale tak należy interpretować te określania, gdyż na to wskazuje wykładnia systemowa art. 4 ust. 1 w zw. $\mathrm{z}$ art. 2 ust. 4 ustawy Republiki Litewskiej o podatku od spadku. Uregulowanie to należy zatem rozumieć $\mathrm{w}$ ten sposób, że przedmiotem podatku

33 Wyrok Naczelnego Sądu Administracyjnego (NSA) z dnia 18 lipca 2017 r., sygn. II FSK 1682/15, LEX nr 2322296.

34 System finansów publicznych..., s. 144.

35 Zob. np. Ustawa z dnia 1 lipca 1926 r. o opłatach stemplowych (Dz.U. RP z 1935 r., Nr 64, poz. 404 - nieobowiązująca) czy Ustawa z dnia 29 maja 1920 r. w przedmiocie zmiany przepisów o opodatkowaniu spadków i darowizn (Dz.U. RP z 1920 r., Nr 49, poz. 299).

36 Dekret z dnia 3 lutego 1947 r. o podatku od nabycia praw majątkowych (Dz.U. z 1951 r., Nr 9, poz. 74 ze zm.). 
od spadku jest mienie nabyte w drodze spadku przez rezydenta Republiki Litewskiej, położone zarówno na Litwie, jak i za granicą, dla osoby zaś niebędącej rezydentem Republiki Litewskiej mienie ruchome, które wedle przepisów prawa litewskiego podlega rejestracji, i ta rzecz jest lub powinna być wpisana do rejestru na Litwie, jak również nieruchomości położone na Litwie (art. 4 ust. 2 ustawy Republiki Litewskiej o podatku od spadku). Nie budzi jednak w litewskim Kodeksie cywilnym wątpliwości, że spadek nabywa się z chwilą śmierci spadkodawcy albo uprawomocnienia się orzeczenia sądu o uznaniu za zmarłego (art. 5.3 Kodeksu cywilnego RL). Jest to więc rozwiązanie zbliżone do polskich art. 924 i 925 k.c.

Z litewskiej ustawy o podatku od spadku nie wynika wprost, czy nabycie mienia w drodze zapisu windykacyjnego jest nabyciem także w drodze spadku. Jeżeli przez spadek rozumieć (art. 5.1 Kodeksu cywilnego Republiki Litewskiej) - „przejście praw majątkowych, obowiązków i niektórych osobistych praw niemajątkowych zmarłej osoby fizycznej na jej spadkobierców zgodnie z ustawą i (lub) na podstawie testamentu", to bez wątpienia nabycie $\mathrm{w}$ drodze zapisu windykacyjnego mienia byłoby nabyciem w drodze spadku. Przepis art. 5.2.3 Kodeksu cywilnego Republiki Litewskiej określa zapis windykacyjny w taki sposób, że „Testator ma prawo zobowiązania spadkobiercy na podstawie testamentu do wykonania jakiegoś obowiązku (zapis windykacyjny), na rzecz jednej lub kilku osób i osoby te zyskują prawo żądania wykonania tego obowiązku. Zapisobiorcami mogą być zarówno spadkobiercy, jak i inne osoby”. Ostatnie zdanie tego przepisu utwierdza w przekonaniu, że otrzymanie zapisu windykacyjnego powinno być na gruncie ustawy Republiki Litewskiej o podatku od spadku traktowane jak nabycie spadku. Jednakże art. 5.2.5 litewskiego Kodeksu cywilnego w zasadzie nie wyszczególnia, tak jak polski art. $981 \$ 2$ k.c., rodzajowo, co może być przedmiotem zapisu windykacyjnego, ale tylko w postaci opisowej. Mówi się o rzeczy oznaczonej co do tożsamości (art. 5.2.5 ust. 1), wierzytelnościach (art. 5.2.5 ust. 2), rzeczach ruchomych (art. 5.2.5 ust. 3), nieruchomościach (grunty, dom, lokal mieszkalny), przedsiębiorstwach (art. 5.2.5 ust. 4), utrzymaniu innej osoby (art. 5.2.5 ust. 5). Tylko w przypadku, gdy przedmiotem zapisu windykacyjnego jest rzecz oznaczona co do tożsamości, wskazuje się, że staje się ona własnością zapisobiorcy po przyjęciu zapisu, z chwilą przyjęcia spadku. Nie ma tu wątpliwości, że nabycie to jest równoznaczne $\mathrm{z}$ nabyciem spadku i podlega opodatkowaniu tak jak spadek. Prawo cywilne litewskie zna więc instytucję zapisu windykacyjnego. Jest on też dostrzegany w piśmiennictwie, a określa się go mianem 
zapisu windykacyjnego ${ }^{37}$. O charakterze i istocie zapisu windykacyjnego w cywilnym prawie litewskim wypowiadał się Sąd Najwyższy (SN) Litwy, który w wyroku z dnia 24 marca 2016 r. Nr 3K-3-163-969/2016 ${ }^{38}$ wyjaśnił, że „W przypadku gdy na podstawie zapisu windykacyjnego spadkobierca zostaje zobowiązany do przekazania zapisobiorcy rzeczy oznaczonych co do gatunku (rzeczy zamienne), w testamencie powinna być wskazana liczba rzeczy podlegających przekazaniu, a jeżeli zapisobiorców jest więcej niż jeden - również konkretna liczba rzeczy (lub konkretny udział procentowy we wszystkich podlegających przekazaniu rzeczach) przypadająca każdemu zapisobiorcy osobno, lub też obiektywne kryteria, według których liczba podlegających przekazaniu rzeczy lub udział procentowy mogłyby zostać dokładnie ustalone. Warunkiem zapisu windykacyjnego jest to, że prawo decydowania co do przedmiotu obowiązku wynikającego z zapisu windykacyjnego przysługuje spadkodawcy. Jeżeli uprawnionemu udzielono prawa według jego własnego uznania dokonania podziału obrazów, nie jest on ważny". Powyższe poglądy SN Litwy prowadzą do wniosku, że przedmiotem zapisu windykacyjnego w prawie litewskim mogą być także rzeczy oznaczone co do gatunku (rzeczy ruchome).

Trzeba jednak zauważyć, że rozporządzenie Parlamentu Europejskiego i Rady (UE) N 650/2012 w sprawie jurysdykcji, prawa właściwego, uznawania i wykonywania orzeczeń, przyjmowania i wykonywania dokumentów urzędowych dotyczących dziedziczenia oraz w sprawie ustanowienia europejskiego poświadczenia spadkowego ${ }^{39}$ wprawdzie wprost nie używa określenia „zapis windykacyjny”, to jednak np. z treści art. 65 ust. 3 lit. e w zw. z art. 66 ust. 4 wynika, że używa się określenia „beneficjent”, przez które należy rozumieć zapisobiorcę windykacyjnego. Oznacza to, że treść europejskiego poświadczenia spadkowego (art. 68 lit. g przywołanego rozporządzenia) powinna zawierać także wskazania dotyczące beneficjentów (zapisobiorców windykacyjnych). Okoliczność, że prawo litewskie przewiduje tę instytucję, nie stanowi przeszkody do uczynienia w testamencie notarialnym zapisu windykacyjnego sporządzonego np. w Polsce. Świadczy o tym choćby wyrok TSUE z dnia 12 października 2017 r. w sprawie C-218/16 A. Kubicka przeciwko Polsce ${ }^{40}$. W orzeczeniu tym Trybunał wskazał, że „art. 1 ust. 2 lit. 1 rozporządzenia nr 650/2012 należy interpretować

\footnotetext{
37 Lit. Tesamentině iš skirtině per o indicationem.

$38 \mathrm{http}: / /$ www.infolex.Lt/tp/1233229

39 Dz.Urz. UE 2012.201.107 ze zm.

40 www.eur-lex.europa.eu
} 
w ten sposób, że stoi on na przeszkodzie odmowie uznania w państwie członkowskim, którego system prawny nie zna instytucji zapisu windykacyjnego, skutków rzeczowych takiego zapisu z chwilą otwarcia spadku zgodnie $\mathrm{z}$ wybranym przez spadkodawcę prawem właściwym dla dziedziczenia”. Jednakże w prawie litewskim własność tego zapisu przechodzi na uprawnionego $\mathrm{z}$ dniem przyjęcia spadku (zapisu), a nie $\mathrm{z}$ dniem otwarcia spadku.

Oczywiście, litewski Kodeks cywilny (art. 5.1) zna też określenie „spadek". Z przepisu tego wynika, że:

„1. Spadek - przejście praw majątkowych, obowiązków i niektórych osobistych praw niemajątkowych zmarłej osoby fizycznej na jej spadkobierców zgodnie z ustawą i (lub) na podstawie testamentu.

2. Spadek stanowią rzeczy materialne (nieruchomości i rzeczy ruchome) oraz rzeczy niematerialne (papiery wartościowe, patenty, znaki towarowe i inne), wierzytelności i zobowiązania majątkowe spadkodawcy w przypadkach określonych przepisami prawa, własność intelektualna (autorskie prawa majątkowe do dzieł literackich, naukowych i dzieł sztuki, pokrewne prawa majątkowe oraz prawa do własności przemysłowej), a także inne określone ustawowo prawa i obowiązki majątkowe.

3. Spadku nie stanowią osobiste prawa niemajątkowe i majątkowe, niepodzielnie związane $\mathrm{z}$ osobą spadkodawcy (prawo do godności i dobrego imienia, autorstwo, prawo do imienia, nietykalności, do alimentów i świadczeń płacowych na utrzymanie spadkodawcy, prawo do emerytury, Z wyjątkiem określonych ustawowo przypadków".

Nie wydaje się, by powyższa definicja spadku była sprzeczna z przedmiotem opodatkowania podatkiem od spadku obowiązującym na Litwie, aczkolwiek art. 4 ust. 1 w zw. z art. 2 ust. 4 ustawy Republiki Litewskiej o podatku od spadku nie wskazuje, by przedmiotem opodatkowania były prawa własności przemysłowej czy majątkowe prawa autorskie. To oznaczałoby, że podlegają one, tak jak w Rzeczypospolitej Polskiej, podatkowi dochodowemu od osób fizycznych (art. 3 pkt 2 u.p.s.d.). Istnieją też wątpliwości, co do tego czy przedmiotem opodatkowania jako spadku jest też nabycie własności rzeczy i praw majątkowych tytułem polecenia testamentowego i polecenia darczyńcy (art. 1 ust. 1 pkt 1 u.p.s.d.) i opodatkowania tego nabycia litewskim podatkiem od spadku. Z jednej strony, gdyby pojęcie „spadek” interpretować zgodnie z art. 5.1.1 Kodeksu cywilnego Republiki Litewskiej, to niewątpliwie byłoby to przejście praw majątkowych (mienia) na podstawie testamentu. Polecenie spadkodawcy (testatora) zawarte 
w testamencie prowadziłoby przecież do nabycia mienia. Z kolei art. 6.467 Kodeksu cywilnego Litwy ${ }^{41}$ stanowi, że przedmiotem polecenia darczyńcy może być obowiązek wykorzystania darowizny w określonym celu. Nie może więc $\mathrm{z}$ istoty rzeczy polecenie darczyńcy, nawet o charakterze majątkowym, prowadzące do nabycia przez inną osobę prawa, prowadzić do powstania obowiązku podatkowego u tej osoby z tytułu nabycia spadku.

Niewątpliwie, przedmiot opodatkowania podatkiem od spadków i darowizn w Polsce jest określony szerzej, bo wchodzą tu w grę wszelkie praktycznie tytuły nabycia rzeczy i praw majątkowych pod tytułem nieodpłatnym, określone w art. 1 ust. 1 pkt 1 pkt 2-6 i ust. 2 u.p.s.d. W ustawie o podatku dochodowym od osób fizycznych obowiązującej w Republice Litewskiej nie mówi się również nic na temat opodatkowania nabycia tytułem polecenia darczyńcy. Jednakże niektóre nieodpłatne świadczenia z tytułu ubezpieczenia na życie, otrzymywane np. na podstawie umowy ubezpieczenia (renty, odprawy, składki), w tym także płacone w przypadku zgonu, uszczerbku na zdrowiu lub choroby ubezpieczonego, podlegają zwolnieniu od podatku dochodowego (art. 17 ust. 1 pkt 7-13 ustawy). Można więc powiedzieć, że wiele tytułów nabycia podlegających w Polsce opodatkowaniu podatkiem od spadków i darowizn na Litwie nie podlega w ogóle obowiązkowi podatkowemu (np. określone w art. 1 ust. 1 pkt 3 i 6 u.p.s.d. - nieodpłatne renta, użytkowanie, służebność, zasiedzenie). Od podatku dochodowego zwolnione są darowizny otrzymane od małżonka, dzieci (dzieci przybranych), rodziców (rodziców zastępczych), braci, sióstr, wnuków i dziadków niezależnie od wartości darowizny. Jeżeli wartość darowizny w okresie objętym obowiązkiem podatkowym nabyta od innych osób łącznie nie przekracza 2500 euro, to również podlegają one zwolnieniu od podatku, a opodatkowuje się tylko nadwyżkę. Od zasady tej istnieje wyjątek, a mianowicie jeżeli darczyńca jest rezydentem państwa uznanego za „raj podatkowy” lub gdy dochody takiej osoby pochodzą ze spółki, która jest zarejestrowana w państwie uznanym za „raj podatkowy”, to takie darowizny nie są zwolnione od podatku dochodowego. Także darowizny otrzymane w czasie kampanii wyborczych przez kandydatów do wyborów - na zasadach ustalonych w odrębnych aktach prawnych - nie podlegają opodatkowaniu.

${ }^{41}$ Artykuł w brzmieniu: „Darczyńca może ustalić w umowie warunek, że darowizna musi być wykorzystana w określonym celu, nie naruszając praw i interesów prawnych innych osób". 
$\mathrm{W}$ istocie rzeczy w piśmiennictwie z zakresu prawa podatkowego zarówno w Polsce ${ }^{42}$, jak i na Litwie ${ }^{43}$ przyjmuje się, że podstawa opodatkowania to jeden $\mathrm{z}$ obligatoryjnych elementów konstrukcyjnych podatku, która wyraża albo ilościowe, albo wartościowe ujęcie przedmiotu opodatkowania. W art. 5 ust. 1 i 2 ustawy Republiki Litewskiej o podatku od spadku wskazuje się bardzo lakonicznie, że „Bazę (podstawę) podatkową stanowi podstawa opodatkowania spadku”, a „Podstawa opodatkowania spadku jest obliczona w trybie określonym przez Rząd Republiki Litewskiej”. Korzystając z upoważnienia zawartego w art. 5 ust. 2 powyższej ustawy, w Rozporządzeniu z dnia 13 stycznia 2003 r. Nr 24 Rada Ministrów Republiki Litewskiej określiła zasady obliczania podstawy opodatkowania spadku. Generalnie z treści tego rozporządzenia wynika, że podatek co do zasady obliczony jest według danych dotyczących wartości przedmiotu opodatkowania, zawartych w odpowiednich katastrach czy rejestrach. Wartość nieruchomości (pkt II.3.1.1 rozporządzenia) określona jest przez Państwowe Centrum Rejestru lub po dokonaniu indywidualnej wyceny nieruchomości: w przypadku papierów wartościowych sprzedawanych na rynku regulowanym - ich średnia wartość rynkowa, a niesprzedawanych na rynku regulowanym - według uznania mieszkańca albo ich wartość nominalna, albo księgowa; dla dzieł sztuki, artystycznych, ruchomych dóbr kultury - wartość ustalona przez Departament Dziedzictwa Kulturowego Ministra Kultury, a dla metali szlachetnych, kamieni szlachetnych itp. - wartość ustalona przez Litewską Izbę Probierczą. Z kolei w przypadku spadku obejmującego inne rzeczy lub papiery wartościowe - wartość ustalona przez rezydenta, który otrzymał spadek (samodzielnie lub przy wykorzystaniu usług rzeczoznawców). Jednocześnie, co ważne, w rozporządzeniu postanowiono, że „Przy obliczaniu podstawy opodatkowania wartość spadku jest pomniejszana o 30\%, co oznacza, że podstawa opodatkowania obejmuje tylko 70\% bazy (podstawy) podatkowej. Jest to więc klasyczna ulga podatkowa polegająca na obniżeniu podstawy opodatkowania podatkiem od spadków. Ustawa ta w związku z tym ani nie posługuje się wartością

${ }^{42}$ A. Kostecki, Elementy..., s. 178; A. Mariański, Komentarz do art. 7 pkt 1, [w:] S. Babiarz, A. Mariański, W. Nykiel, Ustawa o podatku od spadków i darowizn. Komentarz, Warszawa 2010, LEX/el.; S. Babiarz, Spadek i darowizna w prawie cywilnym i podatkowym, Warszawa 2018, s. 909 i n.

43 System finansów publicznych..., s. 146. 
czystą, ani też nie wskazuje, by od wartości rynkowej należało odliczać długi i ciężary. Wartość rynkową bądź inną księgową, rejestrową, oblicza się przy wykorzystaniu urzędowych danych. Powoduje to, że w istocie wymiar tego podatku od spadków jest bardzo prosty i z pewnością nie wywołuje poważnych sporów. Wątpliwości budzi natomiast to, że sposób obliczenia wartości spadku, kwotę bazową niższą o 30\% od wartości rynkowej określono w rozporządzeniu Rady Ministrów, a nie w ustawie. Oznaczałoby to, że w świetle art. 127 ust. 3 Konstytucji RL podstawa opodatkowania nie musi być objęta ustawą podatkową, czyli nie zalicza się jej, jeżeli chodzi o jej konkretyzację (sposób obliczenia, moment obliczenia, kwotę bazową), do istotnych elementów podatku. Podobnie zresztą jest w przypadku rozporządzenia wykonawczego do ustawy Republiki Litewskiej o podatku dochodowym od osób fizycznych, które określa zasady ustalania w niektórych przypadkach ceny mienia nabywanego przez osobę fizyczną nieprowadzącą działalności na własny rachunek.

Z kolei zgodnie z art. 7 ust. 1 i 2 u.p.s.d. „podstawę opodatkowania podatkiem od spadków i darowizn stanowi wartość nabytych rzeczy i praw majątkowych po potrąceniu długów i ciężarów (czysta wartość), ustalona według stanu rzeczy i praw majątkowych w dniu nabycia [w rozporządzeniu do litewskiej ustawy o podatku od spadków jest to dzień złożenia wniosku o ustalenie wartości spadku] i praw majątkowych w dniu nabycia i cen rynkowych z dnia powstania obowiązku podatkowego. [...] Jeżeli spadkobierca, obdarowany lub osoba, na której rzecz został uczyniony zapis zwykły lub windykacyjny, zostali obciążeni obowiązkiem wykonania polecenia lub zapisu zwykłego, wartość obciążenia z tego tytułu stanowi ciężar spadku, darowizny, zapisu zwykłego lub windykacyjnego, a w przypadku polecenia, o ile zostało wykonane”. Wedle zaś art. 8 ust. 1 i 3 u.p.s.d. „Wartość nabytych rzeczy i praw majątkowych przyjmuje się w wysokości określonej przez nabywcę, jeżeli odpowiada ona wartości rynkowej tych rzeczy i praw, a wartość praw do wkładów oszczędnościowych - w wysokości tych wkładów”. „Wartość rynkową rzeczy lub praw majątkowych określa się na podstawie przeciętnych cen stosowanych w obrocie rzeczami tego samego rodzaju i gatunku, z uwzględnieniem miejsca ich położenia, stanu i stopnia zużycia oraz w obrocie prawami majątkowymi tego samego rodzaju, z dnia powstania obowiązku podatkowego". W przepisie art. 8 ust. 4 u.p.s.d. określono, że „Jeżeli nabywca nie określił wartości nabytych rzeczy lub praw majątkowych albo wartość określona przez niego nie odpowiada, według oceny naczelnika urzędu skarbowego, wartości rynkowej, 
organ ten wezwie nabywcę do jej określenia, podwyższenia lub obniżenia, w terminie nie krótszym niż 14 dni od dnia doręczenia wezwania, podając jednocześnie wartość według własnej, wstępnej oceny. Jeżeli nabywca, pomimo wezwania, nie określił wartości lub podał wartość nieodpowiadającą wartości rynkowej, naczelnik urzędu skarbowego dokona jej określenia z uwzględnieniem opinii biegłego lub przedłożonej przez nabywcę wyceny rzeczoznawcy".

Taki sposób ustalania podstawy opodatkowania rodzi wiele problemów, poczynając od tych, czy dany dług (ciężar) mają wpływ i kiedy na podstawę opodatkowania, np. czy są długiem spadku koszty związane z rzeczą lub obniżeniem jej wartości wskutek upływu czasu ${ }^{44}$, czy długiem spadku jest już prawo do zachowku, czy dopiero zachowek wypłacony ${ }^{45}$, czy długiem spadku są koszty osobistej opieki nad spadkodawcą poniesione przez spadkobiercę $^{46}$. W wyroku z dnia 17 listopada 2016 r. (LEX nr 2254613) Wojewódzki Sąd Administracyjny (WSA) w Warszawie przyjął, że „Przez wartość określoną, o której mowa w art. 8 ust. 4 u.p.s.d., należy rozumieć nie kwotę wyliczoną przez biegłego, ale przyjętą przez organ podatkowy do wymiaru podatku.

\section{STAWKA PODATKU}

W ustawie Republiki Litewskiej o podatku od spadku także bardzo prosty jest sposób określenia stawki podatku. Artykuł 6 tej ustawy wskazuje, że „Podatek jest obliczony w procentach od podstawy opodatkowania spadku z zastosowaniem poniższych stawek:

1) jeżeli podstawa opodatkowania spadku nie przekracza 150000 euro $-5 \%$;

2) jeżeli podstawa opodatkowania przekracza 150000 euro - 10\%”.

${ }^{44} \mathrm{~W}$ wyroku z dnia 3 listopada 2004 r., sygn. III SA 2261/03, LEX nr 176958, NSA wyjaśnił, że nie są one długiem spadku.

45 W wyroku z dnia 28 stycznia 2014 r., sygn. II FSK 558/12, „Przegląd Orzecznictwa Podatkowego" 2014, nr 3, s. 281-286, NSA wyjaśnił, że tylko zachowek wypłacony jest długiem spadku. Zachowek jest to tzw. obligatoryjna część spadku, do której prawo w postaci równowartości mają najbliższe spadkodawcy osoby. Nazywa się go też nierozrządzoną częścią spadku, rezerwą itp.

${ }^{46}$ W wyroku z dnia 30 stycznia 2017 r., sygn. I SA/Kr 1292/16, LEX nr 2239367, WSA w Krakowie wyjaśnił, że nie stanowią one długu spadku. 
Powyższa regulacja oznacza, że dla kwoty 153000 euro kwota podatku wynosiłaby:

- 153000 euro - 3000 euro (kwota wolna od podatku) = 150000 euro, co przy kursie euro ok. 4,30 zł daje $645000 \mathrm{zl}$,

- 5\% z kwoty $645000 \mathrm{zł}=32250 \mathrm{zł}$.

Stawkę tę określa więc ustawa, ale w Republice Litewskiej są też podatki, w których określenie stawki podatkowej deleguje się do wskazania jej przez radę samorządową (podatek od nieruchomości, gruntowy czy zryczałtowany podatek dochodowy). Wówczas jednak wyraźnie są określone wszystkie kryteria ich ustalenia. W Polsce zresztą jest podobnie w przypadku podatków od nieruchomości, leśnego i rolnego ${ }^{47}$. Wskazana wyżej stawka podatku od spadku to stawka procentowa. Nie wdając się w spory o to, co to jest stawka podatku, należy tylko zauważyć, że określa się ją w zależności od efektów, które powodują w zakresie kształtowania się stosunku pomiędzy kwotą podatku a podstawą opodatkowania przy jej zmianie. Stawki procentowe stosuje się tam, gdzie podstawa opodatkowania jest wyrażona w jednostkach pieniężnych. Natomiast w ustawie o podatku od spadków i darowizn (art. 15 ust. 1 u.p.s.d.) zastosowano trzy skale progresywne, co oznacza, że stawki tego podatku rosną wraz ze zwiększeniem się podstawy opodatkowania ${ }^{48}$, a w dodatku zastosowano tzw. progresję odcinkową, której istota polega na zastosowaniu odpowiednich stawek do poszczególnych odcinków podstawy opodatkowania, a kwotę podatku stanowi suma tak obliczonych składników. W art. 15 ust. 1 u.p.s.d. postanowiono, że od nabywców zaliczonych do I grupy podatkowej:

- do 10278 zł podatek wynosi 3\%;

- od 10278 zł do 20556 zł podatek wynosi 308 zł 30 gr i 5\% nadwyżki ponad $10278 \mathrm{zk}$;

- od 20556 zł podatek wynosi 822 zł 20 gr i 7\% nadwyżki ponad 20556 zł.

Gdyby zatem przyjąć, że wartość spadku (czysta wartość spadku stanowiąca podstawę opodatkowania) w Polsce wynosiłaby kwotę 654637 zł $(645000 \mathrm{zł}+9637 \mathrm{zł} \mathrm{kwota} \mathrm{wolna} \mathrm{od} \mathrm{podatku),} \mathrm{to} \mathrm{w} \mathrm{Polsce} \mathrm{podatnik} \mathrm{zapła-}$ ciłby podatek w wysokości ( $645000 \mathrm{zl}-22556 \mathrm{zł}=822,20 \mathrm{zł}+7 \% \mathrm{z}$ kwoty $622444 \mathrm{zl}=44393 \mathrm{zl}$.

47 System finansów publicznych..., s. 146.

48 W. Nykiel, Komentarz do art. 15 pkt 1, [w:] S. Babiarz, A. Mariański, W. Nykiel, Ustawa o podatku od spadków i darowizn... 
Powyższe prowadzi do wniosku, że od tej samej wartości podstawy opodatkowania podatnik w Polsce zapłaciłby wyższy podatek niż na Litwie.

Co istotne, w art. 7 ust. 1 pkt 3 ustawy Republiki Litewskiej o podatku od spadków postanowiono, że „Podatek nie ma zastosowania wobec: [...] podstawy opodatkowania spadku nieprzekraczającej 3000 euro”. W polskiej ustawie o podatku od spadków i darowizn przewidziano w art. 9 ust. 1 pkt 1-3 u.p.s.d. opodatkowanie nabycia przez nabywcę, od jednej osoby, własności rzeczy i praw majątkowych o wartości czystej przekraczającej:

1) 9637 zł - jeżeli nabywca jest osobą zaliczaną do I grupy podatkowej (małżonek, zstępny, wstępny, pasierb, zięć, synowa, rodzeństwo, ojczym, macocha i teściowie);

2) $7276 \mathrm{zł}$ - jeżeli nabywca jest osobą zaliczoną do II grupy podatkowej (zstępni rodzeństwa, rodzeństwo rodziców, zstępni i małżonkowie pasierbów, małżonkowie rodzeństwa i rodzeństwo małżonków, małżonkowie rodzeństwa małżonków, małżonkowie innych zstępnych);

3) 4902 zł - jeżeli nabywcą jest osoba zaliczana do III grupy podatkowej (inni nabywcy).

Wskazane kwoty to tzw. kwoty wolne od podatku (minimum podatkowe) polegające na tym, że „podatnik uiszcza podatek dopiero po przekroczeniu pewnej granicy dochodu lub wartości nabywanego majątku”"

Istota tego wyłączenia (minimum podatkowego) polega na tym, że kumuluje się kwoty otrzymane od jednej osoby. Jeżeli dany nabywca otrzymał np. darowiznę (spadek, zapis) od kilku osób (ojca, matki, dziadka i babci), to kwotę wolną oblicza się w stosunku do każdego nabycia od tych osób. Jeżeli zaś otrzymałby dwie darowizny od jednej osoby po 9000 zł, to łącznie otrzymałby $18000 \mathrm{zł}$, i gdyby był zaliczony do I grupy podatkowej, to podstawa opodatkowania wynosiłaby u tego nabywcy $9000 \mathrm{zł}+9000 \mathrm{zł}=$ $18000 \mathrm{zl}-9637 \mathrm{zl}=8363 \mathrm{zl}$.

Z treści przepisów ustawy Republiki Litewskiej o podatku od spadków nie wynika, by znajdowały się w niej instytucje kumulacji przedmiotowej, a kwota 3000 euro jest instytucją minimum podatkowego tak jak w polskiej ustawie o podatku od spadków i darowizn, skoro podatek nie ma zastosowania do podstawy opodatkowania nieprzekraczającej 3000 euro. Ustawa ta jednakże kwotę tę nazywa ulgą podatkową.

${ }^{49}$ W. Nykiel, Ulgi i zwolnienia..., s. 26. 
8. UlGi I ZWOLNIENIA

W art. 7 ust. 1 pkt 1-3 ustawy Republiki Litewskiej o podatku od spadków wskazano, że:

„a) nie pobiera się podatku od spadku małżonka po śmierci drugiego małżonka”, co oznacza, że nabycie przez współmałżonka w spadku po małżonku mienia nie podlega opodatkowaniu;

„b) nie pobiera się podatku od nabycia spadku należnego dzieciom (dzieciom adoptowanym), rodzicom (rodzicom przybranym), opiekunom, podopiecznym, dziadkom, wnukom, braciom i siostrom";

„c) nie opodatkowuje się podatkiem spadku nieprzekraczającego wartości 3000 euro”.

Porównując powyższych podatników uprawnionych do ulgi podatkowej z grupą uprawnionych do zwolnienia podmiotowego w polskiej ustawie o podatku od spadków i darowizn, należy dojść do wniosku, że są one zakresowo zbliżone, o ile uznamy, iż zakresowo opiekunowie i podopieczni to pasierbowie, ojczym i macocha. Można też zaryzykować twierdzenie, że pradziadkowie i prawnuki jako uprawnieni do zwolnienia nie mają praktycznie większego znaczenia.

Z punktu widzenia elementów konstrukcji podatku ulga określona wyżej pod lit. a jest typowym zwolnieniem podmiotowym, ulga określona pod lit. b także, a ulga wskazana pod lit. c to minimum podatkowe. Jest tak dlatego, że podmioty określone wyżej pod lit. a i b są objęte zakresem podmiotowym podatku od spadku, gdyż podatnikami są wszystkie osoby fizyczne. W ustawie tej nie występują wprost ulgi podatkowe rozumiane jako:

a) zmniejszenie podstawy opodatkowania,

b) obniżenie stawki podatkowej,

c) bezpośrednie obniżenie podatku.

Występują natomiast potrącenia $\mathrm{z}$ kwoty podatku, a więc jako ulga podatkowa (art. 9 ust. 1-4 ustawy Republiki Litewskiej o podatku od spadku).

Ulga ta polega na możliwości potrącenia:

- przez stałego mieszkańca Litwy z kwoty podatku od spadku obliczonego w trybie przewidzianym w ustawie kwoty ustalonego podatku od spadku lub kwoty identycznej z nim, zapłaconego w państwie zagranicznym od spadku znajdującego się w tym państwie, jeżeli państwo to znajduje się na liście zatwierdzonej przez ministra finansów, z tym że,

- jeżeli kwota podatku od spadku otrzymanego w państwie zagranicznym, obliczona w trybie przewidzianym w ustawie, jest niższa niż kwota 
ustalonego podatku od spadku lub podatku tożsamego zapłacona od spadku otrzymanego w państwie zagranicznym, potrąceniu podlega wyłącznie kwota podatku od spadku naliczona zgodnie $\mathrm{z}$ ustawą od podatku od spadku obowiązującą na Litwie, jednakże w przypadku gdy

- stały mieszkaniec Litwy otrzymuje spadek w kilku państwach zagranicznych, podlegająca potrąceniu kwota podatku od spadku jest naliczana osobno w przypadku każdego państwa, w którym znajduje się spadek.

Warunkiem niezbędnym do dokonania potrącenia $z$ naliczonej kwoty podatku jest przedłożenie uwierzytelnionych przez organ podatkowy państwa zagranicznego dokumentów o znajdującym się w tym państwie spadku oraz naliczonym i zapłaconym od niego podatku od spadku w ustalonej wysokości lub podatku tożsamego.

Istotne wydaje się to, że w przypadku polskiego podatku od spadków i darowizn podatkiem tożsamym byłby podatek zapłacony od przedmiotów opodatkowania uregulowanych $\mathrm{w}$ ustawie o podatku od spadków i darowizn. Instytucji podobnej, która polegałaby na potrąceniu podatku od spadków i darowizn zapłaconego w innym państwie, w Polsce nie ma. Podwójne opodatkowanie podatkiem od spadków i darowizn jest poważnym problemem nie tylko w państwach Unii Europejskiej (UE). Jest ono łagodzone przez zwolnienia podmiotowe i przedmiotowe. W polskiej ustawie o podatku od spadków i darowizn występuje ulga mieszkaniowa oraz zwolnienia przedmiotowe i podmiotowe.

Ulga mieszkaniowa (art. 16 u.p.s.d.) polega na niewliczaniu do podstawy opodatkowania czystej wartości, własności (współwłasności) budynku mieszkalnego lub lokalu mieszkalnego stanowiącego odrębną nieruchomość, spółdzielczego własnościowego prawa do lokalu mieszkalnego lub udziału w takim prawie, spółdzielczego prawa do domu jednorodzinnego albo udziału w takim prawie, nabytych w drodze dziedziczenia, zapisu zwykłego, zapisu windykacyjnego, dalszego zapisu, polecenia testamentowego, darowizny lub polecenia darczyńcy (dla I grupy podatkowej), albo nabytych w drodze dziedziczenia, zapisu zwykłego, zapisu windykacyjnego, dalszego zapisu lub polecenia testamentowego (dla osób zaliczonych do II grupy podatkowej), albo nabytych w drodze dziedziczenia, zapisu zwykłego, zapisu windykacyjnego, dalszego zapisu lub polecenia testamentowego (dla osób zaliczonych do III grupy podatkowej, które jednocześnie sprawowały opiekę nad wymagającym jej spadkodawcą na podstawie umowy pisemnej z podpisem notarialnie potwierdzonym przez co najmniej dwa lata od dnia poświadczenia podpisu przez notariusza). Nabywca równocześnie nie 
może być właścicielem innego domu jednorodzinnego lub lokalu mieszkalnego, nawet wynajmowanego. Odliczenie ma charakter ryczałtowy obliczony dla $110 \mathrm{~m}^{2}$ powierzchni użytkowej budynku lub lokalu. Z kolei ulgę tę, podobnie jak opisane niżej zwolnienia przedmiotowe i podmiotowe, stosuje się także do nabywcy, który w chwili nabycia posiadał obywatelstwo polskie lub obywatelstwo jednego z państw członkowskich Unii Europejskiej lub państw członkowskich Europejskiego Porozumienia o Wolnym Handlu (EFTA) - stron umowy o Europejskim Obszarze Gospodarczym lub który miał miejsce zamieszkania na terytorium Rzeczypospolitej Polskiej lub na terytorium takiego państwa.

$\mathrm{Z}$ kolei zwolnienia przedmiotowe uregulowane w art. 4 u.p.s.d. są zróżnicowane zarówno co do przedmiotu, bo dotyczą np. nabycia gruntów rolnych, pieniędzy, wkładów na rachunku bankowym, dzieł sztuki, zabytków ruchomych i nieruchomych przez osoby zaliczane do którejś z grup podatkowych i na podstawie któregoś z tytułów nabycia, np. dziedziczenia, darowizny. Natomiast zwolnienia podmiotowe uregulowane w art. $4 \mathrm{a}$ i 4 b u.p.s.d. dotyczą:

- art. 4a u.p.s.d. - nabycia wszelkich rzeczy lub praw majątkowych bez względu na ich wartość przez małżonka, zstępnych, wstępnych, pasierba, rodzeństwo, ojczyma i macochę bez względu na tytuł nabycia, z wyjątkiem nabycia w drodze zasiedzenia;

- art. 4b u.p.s.d. - nabycia w drodze dziedziczenia lub zapisu windykacyjnego własności przedsiębiorstwa osoby fizycznej lub udziału w nim, pod warunkiem m.in. prowadzenia go przez nabywcę co najmniej przez 2 lata i bez względu na jego wartość.

W związku z uregulowaniem zawartym w art. 9 ustawy Republiki Litewskiej o podatku od spadku należy zauważyć, że instytucje unijne nie pozostają bezczynne wobec faktu podwójnego opodatkowywania nabycia spadku. Z inicjatywy Komisji Europejskiej przeprowadzono konsultacje społeczne ${ }^{50}$, a w dniu 15 grudnia 2011 r. Komisja przedstawiła pakiet dokumentów dotyczących rozwiązywania transgranicznych problemów podatkowych powiązanych z dziedziczeniem, a w tym: komunikat COM/2011/864; dokument roboczy SEC/2011/1488; zalecenia 2011/856/EU. W tym ostatnim dokumencie zobowiązano Komisję do opublikowania 3 lata po jego przyjęciu sprawozdania na temat sytuacji

${ }^{50}$ Zob. http://ec.europa.eu/taxaton_customs/taxation/personal_tax/inheritance/index_ en.htm 
opodatkowania spadków w obrębie UE. Czy i jakie efekty te działania przyniosą, pokaże czas. W każdym razie przykład Litwy jest godny naśladowania także przez Polskę.

\section{INNE ZAGADNIENIA}

Zarówno w Polsce, jak i w Republice Litewskiej podatnicy mają obowiązek składania zeznań podatkowych. W Polsce ponadto w przypadku korzystania ze zwolnień podmiotowych mają też obowiązek złożenia (pod warunkiem utraty zwolnienia i opodatkowania nabycia tak jak u podatników I grupy podatkowej) zgłoszenia, a w przypadku gdy przedmiotem nabycia (darowizna lub polecenie darczyńcy) są pieniądze, obowiązek udokumentowania dowodem wpłaty na rachunek bankowy nabywcy lub przekazem pocztowym. Z art. 8 ust. 1 ustawy o podatku od spadków RL wynikałoby, że uprawnionym i obowiązanym do naliczenia podatku od spadków byłby sąd stwierdzający nabycie spadku. Jednakże przepis ten odnosi się tylko do notariusza. Istotna jest bowiem treść art. 8 ust. 2 tej ustawy, z którego wynika, że mieszkaniec płaci podatek od spadków przed stwierdzeniem nabycia spadku, z wyjątkiem przypadku, gdy rada samorządowa odroczyła termin zapłaty podatku lub zwolniła podatnika z obowiązku jego zapłaty. Sankcją braku zapłaty podatku od spadków jest wówczas niemożliwość stwierdzenia nabycia spadku (art. 8 ust. 3 tej ustawy). Rozwiązanie to jest w pewnym sensie zbieżne $z$ art. 19 ust. 6 u.p.s.d. stanowiącym, że notariusz może sporządzić akt notarialny, przedmiotem którego jest np. zbycie spadku, tylko wówczas, gdy przedłożono do aktu zaświadczenie naczelnika urzędu skarbowego stwierdzające, że należny podatek od spadków i darowizn został zapłacony albo podatnik był od niego zwolniony lub że zobowiązanie uległo przedawnieniu. Charakterystyczne jest to, że ustawa RL o opodatkowaniu spadków nie zawiera instytucji ponownego powstania obowiązku podatkowego, tak jak czyni to ustawa o podatku od spadków i darowizn, która umożliwia opodatkowanie nabycia spadku nawet po upływie kilkudziesięciu lat po jego otwarciu, o ile tylko stwierdzenie nabycia spadku (przez sąd czy notariusza) nastąpiło po upływie tych kilkudziesięciu lat.

Trzeba jeszcze podkreślić, że w Polsce zeznanie podatkowe i zgłoszenie są formularzami, których wzory zostały wprowadzone i ustalone urzędowo przez rozporządzenia Ministra Finansów. W każdym wypadku w Republice Litewskiej o wymiarze podatku od spadków rozstrzyga decyzją urząd skarbowy. 


\section{BiBLIOGRAFIA}

Babiarz S., Spadek i darowizna w prawie cywilnym i podatkowym, Warszawa 2018.

Etel L., Opodatkowanie dochodu w wybranych krajach Europy Srodkowej i Wschodniej, Białystok 2006.

Fedorowicz Z., Finanse w gospodarce socjalistycznej, Warszawa 1966.

Gajl N., Finanse i prawo finansowe, Warszawa 1980.

Kostecki A., Elementy konstrukcji podatku, [w:] System instytucji prawno-finansowych $P R L$, t. 3: Instytucje budżetowe, cz. 2: Dochody i wydatki budżetu, red. M. Weralski, Ossolineum, Wrocław 1985.

Mariański A., Komentarz do art. 7 pkt 1, [w:] S. Babiarz, A. Mariański, W. Nykiel, Ustawa o podatku od spadków $i$ darowizn. Komentarz, Warszawa 2010.

Medelieně A., Sudavičius B., Mokesčius teisě, Vilnius 2011.

Mikielewicz A., Warunki życia i pracy w krajach Europejskiego Obszaru Gospodarczego, Białystok 2012.

Nita A., Stosunek prawnopodatkowy, Kraków 1999.

Nykiel W., Komentarz do art. 15 pkt 1, [w:] S. Babiarz, A. Mariański, W. Nykiel, Ustawa o podatku od spadków i darowizn. Komentarz, Warszawa 2010.

Nykiel W., Ulgi i zwolnienia w konstrukcji prawnej podatku, Warszawa 2002.

Ostrowski K., Prawo finansowe. Zarys ogólny, Warszawa 1970.

Reniger H., Prawo finansowe, red. L. Kurowski, Warszawa 1955.

System finansów publicznych Polski i Litwy, red. S. Presnarowicz, B. Sudavičius, Białystok 2017.

Zawora J., Samodzielność finansowa gmin w świetle uwarunkowań prawnych i samorzadowych wydatków inwestycyjnych, „Finanse Komunalne” 2014, nr 10.

\section{TAXATION OF PROPERTY AND PROPERTY RIGHTS ACQUIRED FREE \\ of CHARGE IN THE TAX LAW OF POLAND AND LithuaNia}

\section{SELECTED PROBLEMS}

Summary. The presented comparisons clearly show that the inheritance tax applicable in the Republic of Lithuania is a simple tax, uncomplicated both in legal and financial scope. Therefore, it does not cause serious practical problems in terms of payment or assessment. Its calculation and assessment are friendly for taxpayers. With respect to this, one should particularly note such solutions as lowering the tax base by $30 \%$, non-deductibility of debts and burdens and the complicated procedure for its determination, respect for the principle of avoiding double taxation, or the fact that a new tax obligation may not occur.

This cannot be said about the inheritance and donation tax applicable in Poland. The only thing that can be said in favour of the solutions in force in Poland is that the scope of the discussed tax is wider, which means a number of obtained items cannot be burdened with higher income tax on natural persons.

The author envisages this publication as a first in a series of publications that will inform Polish taxpayers, tax authorities and lawmakers of the legal solutions in force within the scope of taxation of gratuitous acquisition of property and property rights in other selected European countries. The Polish Act on inheritance and donation tax is exceedingly complicated, causes tax disputes, does not 
facilitate establishing correct relations between taxpayers and tax authorities, and undoubtedly also leads to family conflicts.

Keywords: inheritance, donation, debt collection, ordinary entry, further entry, entity, subject of taxation, tax base, reliefs and exemptions, inheritance tax in force in the Republic of Lithuania, Act on inheritance and gift tax 